\title{
Informasi Elektronik Sebagai Bukti dalam Perkara Pidana
}

\author{
Oleh: Nur Ro'is*
}

\begin{abstract}
The development of technological progress is always accompanied by the legal issues that arise in comparative law left behind by developments there. Electronic information as a result of developments in information technology that are so fast to bring the problems associated with proving particularly in the realm of criminal procedural law in which evidence is still adheres to traditional proofs, which is based on evidence that conventional.
\end{abstract}

Keywords : Electronic information, evidence, electronic evidence

\section{Pendahuluan}

Perkembangan teknologi informasi yang semakin pesat dan menyebar hampir keseluruhan bidang kemasyarakatan. Perkembangan di bidang teknologi informasi juga mempengaruhi aspek-aspek hukum berlaku. Batas-batas wilayah suatu negara serasa tidak berarti lagi dengan perkembangan teknologi informasi yang ada, hubungan antara satu belahan dunia ke belahan dunia yang lain dilakukan dalam tempo hitungan detik. Transaksi-transaksi antar wilayah negara dilakukan secara jarak jauh dan bisa dilakukan kapan saja. Pihak-pihak pelaku transaksi tersebut hanya berpegang kepada azas kepercayaan dan bukti berupa data elektronik yang mereka pegang. Pemanfaatan teknologi informasi, media, dan komunikasi telah mengubah baik perilaku masyarakat maupun peradaban manusia secara global. Teknologi informasi saat ini menjadi pedang bermata dua karena selain memberikan kontribusi bagi peningkatan kesejahteraan, kemajuan, dan peradaban manusia, sekaligus menjadi sarana efektif perbuatan melawan hukum.

Saat ini telah lahir suatu rezim hukum baru yang dikenal dengan hukum siber atau hukum telematika. Hukum siber atau cyber law, secara internasional digunakan untuk istilah hukum yang terkait dengan pemanfaatan teknologi informasi dan komunikasi. Demikian pula, hukum telematika yang merupakan perwujudan dari konvergensi hukum telekomunikasi, hukum media, dan hukum informatika. Istilah lain yang juga digunakan adalah hukum teknologi informasi (law of information technology), hukum dunia maya (virtual world law), dan hukum mayantara.

Istilah-istilah tersebut lahir mengingat kegiatan yang dilakukan melalui jaringan sistem komputer dan sistem komunikasi baik dalam lingkup lokal maupun global (internet) dengan memanfaatkan teknologi informasi berbasis sistem komputer yang merupakan sistem elektronik yang dapat dilihat secara virtual. Permasalahan hukum yang seringkali dihadapi adalah ketika terkait dengan penyampaian informasi, komunikasi, dan/atau transaksi secara elektronik, khususnya dalam hal pembuktian dan hal yang terkait dengan perbuatan hukum yang dilaksanakan melalui sistem elektronik.

Aktivitas dalam ruang cyber bersifat virtual yang berdampak sangat nyata, sekalipun alat buktinya bersifat elektronik, sebagai contoh dalam kegiatan electronic commerce antara lain diintrodusir adanya dokumen elektronik yang memiliki kedudukan yang disetarakan dengan dokumen yang dibuat secara tertulis diatas kertas

\footnotetext{
* Dosen PNSD Kopertis Wilayah II DPK di FISIP UNBARA
} 
Dengan demikian, subjek pelakunya harus dikualifikasikan pula sebagai orang yang telah melakukan perbuatan hukum secara nyata. Dalam kegiatan e-commerce antara lain dikenal adanya dokumen elektronik yang kedudukannya disetarakan dengan dokumen yang dibuat di atas kertas.

Berkaitan dengan hal itu, perlu diperhatikan sisi keamanan dan kepastian hukum dalam pemanfaatan teknologi informasi, media, dan komunikasi agar dapat berkembang secara optimal. Oleh karena itu, terdapat tiga pendekatan untuk menjaga keamanan di cyberspace, yaitu pendekatan aspek hukum, aspek teknologi, aspek sosial, budaya, dan etika. Untuk mengatasi gangguan keamanan dalam penyelenggaraan sistem secara elektronik, pendekatan hukum bersifat mutlak karena tanpa kepastian hukum, persoalan pemanfaatan teknologi informasi menjadi tidak optimal.

\section{Inti Permasalahan}

Permasalahan hukum yang sering dihadapi adalah terkait dengan "penyampaian informasi, komunikasi dan atau transaksi secara elektronik" khususnya dalam konteks penerapan pembuktian dan hal lain yang terkait dengan perbuatan hukum yang dilaksanakan melalui sistem elektronik.

Informasi elektronik menjadi suatu hal yang baru dalam hukum pidana Indonesia dikarenakan landasan Hukum Acara Pidana Indonesia yaitu UU No. 8 Tahun 1981 sama sekali tidak mengenal informasi elektronik sebagai salah satu alat bukti yang sah.

Informasi elektronik sendiri memiliki pengertian sebagai satu atau sekumpulan data elektronik, termasuk tetapi tidak terbatas pada tulisan, suara, gambar, peta, rancangan, foto, electronic data interchange (EDI), surat elektronik (electronic mail), telegram, teleks, telecopy atau sejenisnya, huruf, tanda, angka, kode akses, simbol, atau perforasi yang telah diolah yang memiliki arti atau dapat dipahami oleh orang yang mampu memahaminya (UU No 11 Tahun 2008 Pasal 1 Angka 1).

Dalam perkara pidana juga terjadi pergeseran pandangan umum terhadap alat bukti itu sendiri seiring dengan perkembangan teknologi informasi ini. Bukti berupa informasi elektronik sebagai hasil dari teknologi informasi menjadi hal yang diperdebatkan mengenai keabsahannya dalam pembuktian.

Tulisan ini mencoba mengangkat permasalahan "Bagaimana kedudukan informasi elektronik sebagai alat bukti yang sah dalam perkara pidana?" Dalam tulisan ini pembahasan pertanyaan dibatasi hanya pada; teori umum tentang pembuktian dan kedudukan informasi elektronik sebagai alat bukti yang sah dalam undang-undang.

\section{Teori Pembuktian Pidana}

Pembuktian merupakan bagian dari hukum acara pidana, menurut Andi Hamzah tujuan dari hukum acara pidana adalah mencari kebenaran materiil itu adalah sebagian dari tertib hukum indonesia yaitu menuju masyarakat yang tertib, tentram, adil dan sejahtera (Andi Hamzah, 1984, Hal 18).

Menurut R. Subekti, membuktikan ialah meyakinkan hakim tentang kebenaran dalil atau dalil-dalil yang dikemukakan dalam suatu persengketaan. Lebih lanjut dikatakan bahwa pembuktian itu hanyalah diperlukan dalam persengketaan atau "perkara" di muka hakim atau pengadilan. Kemudian Sudikno Mertokusumo, menerangkan bahwa pembuktian mengandung beberapa pengertian, yaitu arti logis, konvensional dan yuridis. Membuktikan dalam arti logis adalah memberikan kepastian dalam arti mutlak, karena berlaku bagi setiap orang dan tidak memungkinkan adanya bukti lawan. Untuk membuktikan dalam arti konvensional, disinipun membuktikan berarti juga memberikan kepastian, hanya saja bukan kepastian mutlak, melainkan kepastian nisbi atau relatif 
sifatnya. Dan membuktikan dalam arti yuridis berarti memberi dasar yang cukup kepada hakim yang memeriksa perkara yang bersangkutan guna memberi kepastian tentang kebenaran peristiwa yang diajukan. Dengan demikian membuktian adalah suatu cara yang diajukan oleh pihak yang berperkara di muka persidangan atau pengadilan untuk memberikan dasar keyakinan bagi hakim tentang kepastian kebenaran suatu peristiwa yang terjadi (Yuyun Yuliana, 2002:7).

Secara umum teori sistem pembuktian dalam hukum acara pidana dapat secara singkat diuraikan sebagai berikut (Reda Mantovani, 2008 Hal.38):

a. Sistem pembuktian conviction-in time menentukan salah tidaknya seorang terdakwa semata-mata ditentukan oleh penilian "keyakinan hakim". Keyakinan hakim menentukan keterbuktian kesalahan terdakwa. Darimana hakim menarik dan menyimpulkan keyakinannya tidak menjadi masalah dalam sistem ini. Keyakinan boleh diambil dan disimpulkan hakim dari alat-alat bukti yang diperiksanya dalam sidang pengadilan. Bias juga hasil pemeriksaan alat-alat bukti itu diabaikan hakim dan langsung menarik keyakinan dari keterangan terdakwa;

b. Sistem pembuktian conviction-rasionee, dalam sistem ini pun dapat dikatakan keyakinan hakim tetap memegang peranan penting dalam menentukan salah tidaknya terdakwa. Akan tetapi dalam sistem pembuktian ini faktor keyakinan hakim dibatasi, yakni harus didukung dengan "alas an-alasan yang jelas";

c. Sistem pembuktian menurut undang-undang secara positif merupakan pembuktian yang bertolak belakang dengan sistem pembuktian menurut keyakinan hakim, menurut sistem ini " keyakinan hakim tidak ikut diambil bagian dalam membuktikan kesalahan terdakwa". sistem ini berpedoman pada alat-alat bukti yang ditentukan oleh undangundang. Untuk menentukan salah atau tidaknya terdakwa tergantung pada alat-alat bukti yang sah menurut undang-undang;

d. Sistem pembuktian menurut undang-undang secara negatif, sistem ini merupakan gabungan atara sistem berdasarkan keyakinan hakim dan sistem pembuktian berdasar undang-undang secara positif.

Sumber hukum pembuktian adalah undang-undang, doktrin atau ajaran dan jurisprudensi. Karena hukum pembuktian bagian dari hukum acara pidana, maka sumber hukum yang pertama adalah Undang-Undang Nomor 8 Tahun 1981, Tentang Hukum Acara Pidana atau KUHAP. Lembaran Negara Republik Indonesia Tahun 1981 Nomor 76 dan penjelasannya yang dimuat dalam Tambahan Lembaran Negara Republik Indonesia Nomor 3209. ( Sasangka ,2003 Hal 10).

Apabila di dalam praktik menemui kesulitan dalam penerapannya atau menjumpai kekurangan atau untuk memenuhi kebutuhan maka digunakan doktrin atau yurisprudensi. Alat bukti adalah segala sesuatu yang ada hubungannya dengan suatu perbuatan, dimana dengan alat-alat bukti tersebut, dapat digunakan sebagai bahan pembuktian guna menimbulkan keyakinan hakim atas kebenaran adanya suatu tindak pidana yang telah dilakukan oleh terdakwa.

Sistem pembuktian adalah pengaturan tentang macam-macam alat bukti yang boleh dipergunakan, penguraian alat bukti dan dengan cara-cara bagaimana alat bukti tersebut dipergunakan dan dengan cara bagaimana hakim harus membentuk keyakinannya. Sistem pembuktian yang dianut oleh Indonesia dapat dilihat dalam Undang-Undang No 8 tahun 1981 dalam pasal 183 berbunyi: "Hakim tidak boleh menjatuhkan pidana kepada seseorang kecuali apabila dengan sekurang-kurangnya dua alat bukti yang sah ia memperoleh keyakinan bahwa suatu tindak pidana benar-benar terjadi dan bahwa terdakwalah yang bersalah melakukannya". 
Selanjutnya dalam pasal 184 ayat 1 diatur mengenai alat bukti itu sendiri yaitu: a) Keterangan saksi; b) Keterangan ahli; c) Surat; d) Petunjuk, dan; e) Keterangan terdakwa. Dalam undang-undang tersebut sama sekali tidak disebutkan mengenai informasi elektronik.

\title{
Alat Bukti Informasi Elektronik dalam Undang-Undang
}

Meskipun mengenai alat bukti informasi elektronik tidak disebutkan dalam KUHAP sejak tahun 2001 dalam hukum acara pidana telah mengenal mengenai bukti informasi elektronik dalam Undang-Undang No. 20 Tahun 2001 tentang perubahan Undang-Undang No. 31 Tahun 1999 tentang Tindak Pidana Korupsi. Alat bukti informasi elektronis di introduksi dalam pasal 26A :

\begin{abstract}
“Alat bukti yang sah dalam bentuk petunjuk sebagaimana dimaksud dalam Pasal 188 ayat (2) Undangundang Nomor 8 Tahun 1981 tentang Hukum Acara Pidana, khusus untuk tindak pidana korupsi juga dapat diperoleh dari; a) Alat bukti lain yang berupa informasi yang diucapkan, dikirim, diterima, atau disimpan secara elektronik dengan alat optik atau yang serupa dengan itu, dan; b) Dokumen, yakni setiap rekaman data atau informasi yang dapat dilihat, dibaca, dan atau didengar yang dapat dikeluarkan dengan atau tanpa bantuan suatu sarana, baik yang tertuang di atas kertas, benda fisik apapun selain kertas, maupun yang terekam secara elektronik, yang berupa tulisan, suara, gambar, peta, rancangan, foto, huruf, tanda, angka, atau perforasi yang memiliki makna.”
\end{abstract}

Undang-Undang No. 15 Tahun 2002 jo Undang-Undang No 25 tahun 2003 tentang Tindak Pidana Pencucian Uang dalam pasal 38 jo Pasal 1 butir 7 Undang-Undang No 15 Tahun 2002 jo Pasal 1 butir 9 Undang-Undang No 25 tahun 2003yang mengatur tentang alat bukti berupa informasi elektronik sebagai berikut:

\begin{abstract}
"Dokumen adalah data, rekaman, atau informasi yang dapat dilihat, dibaca, dan/atau didengar, yang dapat dikeluarkan dengan atau tanpa bantuan suatu sarana, baik yang tertuang di atas kertas, benda fisik apapun selain kertas, atau yang terekam secara elektronik, termasuk tetapi tidak terbatas pada: a) Tulisan, suara, atau gambar; b) Peta, rancangan, foto, atau sejenisnya; c) Huruf, tanda, angka, simbol, atau perforasi yang memiliki makna atau dapat dipahami oleh orang yang mampu membaca atau memahaminya."
\end{abstract}

Kemudian dalam PERPU No 1 Tahun 2002 yang telah diundangkan dengan Undang-Undang No. 15 Tahun 2003 Tentang Tindak Pidana Terorisme disebutkan dalam pasal 27;

Pasal 27: Alat bukti pemeriksaan tindak pidana terorisme meliputi: a) Alat bukti sebagaimana dimaksud dalam Hukum Acara Pidana; b) Alat bukti lain berupa informasi yang diucapkan, dikirimkan, diterima, atau disimpan secara elektronik dengan alat optik atau yang serupa dengan itu; c) Data, rekaman, atau informasi yang dapat dilihat, dibaca, dan/atau didengar, yang dapat dikeluarkan dengan atau tanpa bantuan suatu sarana, baik yang tertuang di atas kertas, benda fisik apapun selain kertas, atau yang terekam secara elektronik, termasuk tetapi tidak terbatas pada; (1) Tulisan, suara, atau gambar; (2) Peta, rancangan, foto, atau sejenisnya; (3) Huruf, tanda, angka, simbol, atau perforasi yang memiliki makna atau dapat dipahami oleh orang yang mampu membaca atau memahaminya.

Selanjutnya data elektronik sebagai alat bukti dapat juga ditemukan dalam UndangUndang Nomor 17 Tahun 2006 Tentang Perubahan Atas Undang-Undang Nomor 10 Tahun 1995 Tentang Kepabeanan dalam Pasal 1 point 20 disebutkan: Audit Kepabeanan adalah kegiatan pemeriksaan laporan keuangan, buku, catatan dan dokumen yang menjadi bukti dasar pembukuan, surat yang berkaitan dengan kegiatan usaha termasuk data elektronik, surat yang berkaitan dengan kegiatan di bidang kepabeanan, dan/atau sediaan barang dalam rangka pelaksanaan ketentuan peraturan perundang-undangan di bidang 
kepabeanan. Pada pasal 5A Undang-Undang Nomor 17 Tahun 2006 disebutkan sebagai berikut :

\begin{abstract}
"(1) Pemberitahuan pabean sebagaimana dimaksud dalam Pasal 5 ayat (2) dapat disampaikan dalam bentuk tulisan di atas formulir atau dalam bentuk data elektronik; (2) Penetapan kantor pabean tempat penyampaian pemberitahuan pabean dalam bentuk data elektronik dilakukan oleh Menteri; (3) Data elektronik sebagaimana dimaksud pada ayat (1) merupakan alat bukti yang sah menurut UndangUndang ini; (4) Ketentuan mengenai tata cara sebagaimana dimaksud pada ayat (1) diatur lebih lanjut dengan atau berdasarkan peraturan menteri."
\end{abstract}

Dalam penjelasan pasal 5A ayat (1) Undang-Undang Nomor 17 Tahun 2006 dijelaskan Data elektronik (softcopy) yaitu informasi atau rangkaian informasi yang disusun dan/atau dihimpun untuk kegunaan khusus yang diterima, direkam, dikirim, disimpan, diproses, diambil kembali, atau diproduksi secara elektronik dengan menggunakan komputer atau perangkat pengolah data elektronik, optikal, atau cara lain yang sejenis.

Tahun 2008 menjadi momentum penting dalam perkembangan hukum di Indonesia dengan keluarnya undang-undang yang mengatur mengenai cyberspace yaitu Undangundang no 11 tahun 2008 Tentang Informasi dan Transaksi Elektronik ( UU ITE ). Di dalam undang-undang tersebut dijelaskan mengenai definisi Informasi elektronik ; adalah satu atau sekumpulan data elektronik, termasuk tetapi tidak terbatas pada tulisan, suara, gambar, peta, rancangan, foto, electronic data interchange (EDI), surat elektronik (electronic mail), telegram, teleks, telecopy atau sejenisnya, huruf, tanda, angka, Kode Akses, simbol, atau perforasi yang telah diolah yang memiliki arti atau dapat dipahami oleh orang yang mampu memahaminya Pasal 1 (1).

Selanjutnya dalam Pasal 5 UU No 11 Tahun 2008 disebutkan mengenai sahnya Informasi Elektronik sebagai alat bukti yang sah ;

Pasal 5; 1) Informasi Elektronik dan/atau Dokumen Elektronik dan/atau hasil cetaknya merupakan alat bukti hukum yang sah; 2) Informasi Elektronik dan/atau Dokumen Elektronik dan/atau hasil cetaknya sebagaimana dimaksud pada ayat (1) merupakan perluasan dari alat bukti yang sah sesuai dengan Hukum Acara yang berlaku di Indonesia; 3) Informasi Elektronik dan/atau Dokumen Elektronik dinyatakan sah apabila menggunakan Sistem Elektronik sesuai dengan ketentuan yang diatur dalam Undang- Undang ini, dan; 4) Ketentuan mengenai Informasi Elektronik dan/atau Dokumen Elektronik sebagaimana dimaksud pada ayat (1) tidak berlaku untuk: (a) Surat yang menurut Undang-Undang harus dibuat dalam bentuk tertulis; dan; b) Surat beserta dokumennya yang menurut Undang-Undang harus dibuat dalam bentuk akta notaril atau akta yang dibuat oleh pejabat pembuat akta.

Mengenai persyaratan suatu informasi elektronik dapat digunakan sebagai alat bukti diatur dalam Pasal 6 UU Nomor 11 Tahun 2008 ;

Pasal 6: Dalam hal terdapat ketentuan lain selain yang diatur dalam Pasal 5 ayat (4) yang mensyaratkan bahwa suatu informasi harus berbentuk tertulis atau asli, Informasi Elektronik dan/atau dokumen elektronik dianggap sah sepanjang informasi yang tercantum di dalamnya dapat diakses, ditampilkan, dijamin keutuhannya, dan dapat dipertanggungjawabkan sehingga menerangkan suatu keadaan.

Mengenai bentuk dari dokumen elektronik itu sendiri penjelasan Pasal 6 UU No 11 Tahun 2008 menerangkan bahwa Selama ini bentuk tertulis identik dengan informasi dan/atau dokumen yang tertuang di atas kertas semata, padahal pada hakikatnya informasi dan/atau dokumen dapat dituangkan ke dalam media apa saja, termasuk media elektronik. Dalam lingkup sistem elektronik, informasi yang asli dengan salinannya tidak relevan lagi 
untuk dibedakan sebab sistem elektronik pada dasarnya beroperasi dengan cara penggandaan yang mengakibatkan informasi yang asli tidak dapat dibedakan lagi dari salinannya.

Ketentuan selanjutnya yang mengatur tentang Informasi Elektronik sebagai alat bukti ditemukan dalam Pasal 44 UU No 11 tahun 2008 ;

Pasal 44: Alat bukti penyidikan, penuntutan dan pemeriksaan di sidang pengadilan menurut ketentuan undang-undang ini adalah sebagai berikut: a) Alat bukti sebagaimana dimaksud dalam ketentuan Perundang-undangan, dan; b) Alat bukti lain berupa Informasi Elektronik dan/atau Dokumen Elektronik sebagaimana dimaksud dalam Pasal 1 angka 1 dan angka 4 serta Pasal 5 ayat (1), ayat (2), dan ayat (3).

Ketentuan mengenai Informasi Elektronik berkaitan sebagai alat bukti juga dapat ditemukan dalam Undang-Undang No 44 Tahun 2008 Tentang Pornografi dalam pasal 24;

Pasal 24: Di samping alat bukti sebagaimana diatur dalam undang-undang tentang Hukum Acara Pidana, termasuk juga alat bukti dalam perkara tindak pidana meliputi tetapi tidak terbatas pada: a) Barang yang memuat tulisan atau gambar dalam bentuk cetakan atau bukan cetakan, baik elektronik, optik, maupun bentuk penyimpanan data lainnya, dan; b) data yang tersimpan dalam jaringan internet dan saluran komunikasi lainnya.

\section{Alat Bukti Informasi Elektronik dalam Perkara Tindak Pidana Umum}

Meskipun Undang-undang di Indonesia telah mengenal Informasi Elektronik sebagai salah satu alat bukti akan tetapi secara umum Hukum Acara Pidana Indonesia masih mengacu pada Undang-Undang No. 8 Tahun 1981 sebagai landasan hukum. Dalam Undang-Undang No. 8 Tahun 1981 alat bukti hanya terbatas pada; Keterangan Saksi, Keterangan Ahli, Surat, Petunjuk dan Keterangan Terdakwa. Informasi Elektronik dapat dijadikan sebagai alat bukti pada kasus-kasus yang bersifat khusus di mana undang-undang telah mengaturnya sebagai alat bukti yang sah seperti dalam kasus korupsi, Tindak Pidana Informasi dan Transaksi Elektronik, Pornografi dan Tindak Pidana Kepabeanan.

\section{Informasi Elektronik dalam RUU Tentang Hukum Acara Pidana Indonesia}

Seperti yang telah dijelaskan sebelumnya bahwa informasi elektronik tidak dapat dijadikan sebagai alat bukti dalam tindak pidana umum dikarenakan landasan hukum acara di Indonesia adalah undang-undang No. 8 Tahun 1981 dimana undang-undang tersebut tidak mengenal informasi elektronik sebagai salah satu alat bukti yang sah.

Keterbatasan dalam UU No 8 Tahun 1981 dalam alat bukti ini yang menyebabkan perlu adanya pembaharuan dalam KUHAP. Rancangan Undang-Undang tentang Kitab Undang-Undang Hukum Acara Pidana Draft Tahun 2008 sudah mengenal mengenai bukti elektronik sebagai alat bukti ( Pasal 177 ayat (1).c )

(1) Alat bukti yang sah mencakup: a) barang bukti; b) surat-surat; c) bukti elektronik; d) keterangan seorang ahli; e) keterangan seorang saksi; f) keterangan terdakwa; dan; g) pengamatan Hakim.

Menurut penjelasan pasal 177 ayat (1) huruf c RUU KUHAP Yang dimaksud dengan "bukti elektronik" adalah informasi yang diucapkan, dikirim, diterima, atau disimpan secara elektronik dengan alat optik atau yang serupa dengan itu, termasuk setiap rekaman data atau informasi yang dapat dilihat, dibaca, dan/atau didengar yang dapat dikeluarkan dengan atau tanpa bantuan suatu sarana baik yang tertuang di atas kertas, benda fisik 
apapun selain kertas maupun yang terekam secara elektronik yang berupa tulisan, gambar, peta, rancangan, foto, huruf, tanda, angka, atau perforasi yang memiliki makna.

\section{Penutup}

Dalam Hukum Acara di Indonesia telah mengenal alat bukti Informasi Elektronik sebagai alat bukti yang sah untuk tindak pidana khusus seperti kasus Korupsi, Tindak Pidana Informasi dan Transaksi Elektronik, Pornografi dan Tindak Pidana Kepabeanan. Untuk tindak pidana umum masih mengacu pada UU No. 8 Tahun 1981 Tentang Kitab Undang-Undang Hukum Acara Pidana dimana Informasi Elektronik tidak dikenal sebagai salah satu alat bukti yang Sah. Dengan demikian untuk tindak pidana umum informasi elektronik tidak bisa digunakan sebagai alat bukti yang sah. Dalam Draft Rancangan Undang-Undang tentang Kitab Undang-Undang Hukum Acara Pidana tahun 2008 sudah memuat tentang Informasi elektronik sebagai salah satu alat bukti yang sah baik untuk tindak pidana khusus maupun tindak pidana umum.

\section{DAFTAR PUSTAKA}

Hamzah, Andi. 2004. Hukum Acara Pidana Indonesia. Edisi Revisi. Jakarta: Sinar Grafika

Subekti, R. 1978. Hukum Pembuktian. Jakarta: Pradya Paramita

Manthovani, Reda. 2006. Problematika dan Solusi Penanganan Kejahatan Cyber di Indonesia. Jakarta: PT. Malibu

Undang-Undang Nomor 8 Tahun 1981 Tentang Kitab Undang-Undang Hukum Acara Pidana

Undang-Undang Nomor 20 Tahun 2001 Tentang Perubahan Undang-Undang No 31 Tahun 1999 Tentang Tindak Pidana Korupsi

Undang-Undang Nomor 15 Tahun 2002 jo Undang-Undang No 25 Tahun 2003 Tentang Tindak Pidana Pencucian Uang

Undang-Undang No 15 Tahun 2003 Tentang Tindak Pidana Terorisme

Undang-Undang Nomor 17 Tahun 2006 Tentang Perubahan Atas Undang-Undang Nomor 10 Tahun 1995 Tentang Kepabeanan

Undang-Undang Nomor 11 Tahun 2008 Tentang Informasi dan Transaksi Elektronik

Undang-Undang Nomor 44 Tahun 2008 Tentang Pornografi

Rancangan Undang-Undang Tentang Kitab Undang-Undang Hukum Acara Pidana Tahun 2008 